\title{
Solvent-free microwave extraction of essential oil from Melaleuca leucadendra L.
}

\author{
Aviarina Widya Ismanto ${ }^{1}$, Heri Septya Kusuma ${ }^{1}$, and Mahfud Mahfud ${ }^{1, *}$ \\ ${ }^{1}$ Department of Chemical Engineering, Faculty of Industrial Engineering, Institut Teknologi Sepuluh Nopember, Surabaya, Indonesia \\ 60111
}

\begin{abstract}
Cajuput (Melaleuca leucadendra L.) oil is one of potential commodity that provides an important role for the country's foreign exchange but the extraction of these essential oil is still using conventional method such as hydrodistillation which takes a long time to produce essential oil with good quality. Therefore it is necessary to optimize the extraction process using a more effective and efficient method. So in this study the extraction is done using solvent-free microwave extraction method that are considered more effective and efficient than conventional methods. The optimum yield in the extraction of cajuput oil using solvent-free microwave extraction method is $1.0674 \%$. The optimum yield is obtained on the feed to distiller (F/D) ratio of $0.12 \mathrm{~g} / \mathrm{mL}$ with microwave power of $400 \mathrm{~W}$. In the extraction of cajuput oil using solvent-free microwave extraction method is performed first-order and second-order kinetics modelling. Based on kinetics modelling that has been done, it can be said that the second-order kinetic model $\left(R^{2}=0.9901\right)$ can be better represent experimental results of extraction of cajuput oil that using solvent-free microwave extraction method when compared with the first-order kinetic model $\left(R^{2}=0.9854\right)$.
\end{abstract}

\section{Introduction}

Cajuput (Melaleuca leucadendra L.) oil is one of potential commodity that provides an important role for the country's foreign exchange. It can be obtained from parts of plants including stems, leaves, or fruits. Cajuput oil can be extracted using several methods like hydrodistillation, water-steam distillation, and steam distillation [1].

Melaleuca leucadendra L. or cajuput is a traditional low-growing tree that the leaves can be produced an essential oil. Cajuput oil is used as an herbal remedy such as antiseptic, analgesic, antireumatic, and antiinflammatory [2-4]. Furthermore cajuput oil is also used in cosmetic products, perfume and fragrance industries $[2,5-6]$. The main product from the cajuput plant is cajuput oil that produced by the distillation of cajuput leaves. The cajuput plant in Java Island has a capacity of 53,760 tons per year for cajuput leaves and total annual production of cajuput oil produced in Java by 300 tons [7]. The consumption for cajuput oil is increasing along with the growing variation of the utilization of cajuput oil. In Indonesia, the annual supply of cajuput oil necessity is 1500 tons [8].

Along with the relatively good prospect of cajuput oil in Indonesia, it should be followed by the development of the cajuput oil distillation technology. The cajuput oil is generally extracted using steam distillation, water- steam distillation and hydrodistillation $[1-2,9]$. The disadvantages that used a conventional methods to extract essential oils such as loss of some volatile compounds, high solvent requirements, and long extraction times [10-11]. Microwave energy is an alternative extraction from conventional methods. By using microwave energy, the extraction can be done quickly and reducing solvent consumption. Solvent-free microwave extraction (SFME) is a "green-technology" extraction method that are combining a microwave heat and dry distillation without adding any solvents [12].

In this study the extraction of cajuput oil is examined using solvent-free microwave extraction method. The effect of microwave power on product yield and extraction kinetics model from cajuput oil extraction was also investigated.

\section{Materials and Methods}

\subsection{Materials}

Cajuput leaves (Melaleuca leucadendra L.) were collected from Mojokerto, East Java. Cajuput leaves were gathered from the same plantation age at approximately 6-12 months of plantation.

\footnotetext{
* Corresponding author: mahfud@chem-eng.its.ac.id
} 


\subsection{Solvent-free microwave extraction}

The microwave oven used was Electrolux model EMM$2007 \mathrm{X}$ operating at $2450 \mathrm{MHz}$. The maximum power of the oven was $800 \mathrm{~W}$. Microwave oven was modified by drilling a hole at the top. Sixty grams of fresh cajuput leaves was placed in sample flask in the oven and connected to condensor through the hole. The hole around the neck. During the process, the vapor passed through the condenser outside the microwave cavity where it was condensed. The SFME process was performed for different times and was continued until no more essential oil was obtained. The extraction yield of essential oil was calculated according to Eq. (1).

Extraction yield $=\frac{\text { Mass of extraction essential oil }}{\text { Mass of dried material }} \times 100 \%$ (1)

\subsection{Kinetic Model}

\subsubsection{First-Order Kinetic Model}

Lagergren's kinetic equation for first-order model [1318] can be written in the following differential form:

$\frac{\mathrm{d} C_{t}}{\mathrm{dt}}=k_{1}\left(C_{S}-C_{t}\right)$

where $\mathrm{k}_{1}\left(\mathrm{~min}^{-1}\right)$ is the rate of extraction constant for first-order and $\mathrm{t}(\mathrm{min})$ is the time of extraction.

Eq. (2) has been obtained can be converted into linear form as follows:

$\log \left(C_{S}-C_{t}\right)=\log \left(C_{S}\right)-\frac{k_{1}}{2,303} t$

The extraction capacity, $\mathrm{C}_{\mathrm{S}}$, and the first-order extraction rate constant, $k$, can be determined experimentally from the slope and intercept by $\log \left(\mathrm{C}_{\mathrm{s}}-\right.$ $\mathrm{C}_{\mathrm{t}}$ ) versus time, $\mathrm{t}$.

\subsubsection{Second-Order Kinetic Model}

Second-order model in extraction field means that the extraction occurs in two simultaneous processes [16-20]. The rate of dissolution for the essential oil contained in the solid to solution can be described by Eq (4).

$\frac{\mathrm{d} C_{t}}{\mathrm{dt}}=k_{2}\left(C_{S}-C_{t}\right)^{2}$

where $k_{2}$ is the rate of extraction constant for secondorder $\left(\mathrm{L} \mathrm{g}^{-1} \mathrm{~min}^{-1}\right), C_{S}$ is the extraction capacity $\left(\mathrm{g} \mathrm{L}^{-1}\right)$ and $C_{t}$ is the concentration of cajuput oil at any time $t$ (min).

A linear form shown in Eq. (5) can be obtained and the extraction rate can be written as Eq. (6).

$$
\begin{aligned}
& \frac{t}{C_{t}}=\frac{1}{C_{S}{ }^{2} k_{2}}+\frac{t}{C_{S}} \\
& C_{t}=C_{S}-\frac{C_{S}}{1+C_{S} k_{2} t}
\end{aligned}
$$

The initial extraction rate, $h$, as $C t / t$ when $t$ approaches 0 , can be defined as:

$h=k C_{S}^{2}$

Then ploted between $t / C_{t}$ with time, $t$, to get slope and intercept which can be used to determine the initial extraction rate, $h$, the extraction capacity, $\mathrm{C}_{\mathrm{S}}$, and the second-order extraction rate constant, $k$.

\section{Results and Discussion}

\subsection{Cajuput oil yield}

The yield of cajuput oil was measured throughout the extraction process. Figure 1 shows the more feed to distiller ratio (F/D) used, the increasing weight of cajuput oil. However the amount of raw material (cajuput leaves) and cajuput oil output are not always positively correlated with the increase of cajuput oil yield. These is because of cajuput oil yield was influence by the factor of the ratio of cajuput oil and the amount of raw material. In Figure 1, the optimum yield in the extraction of cajuput oil using solvent-free microwave extraction method is $1.0674 \%$. The yield was decreased in the feed to distiller ratio of $0.14 \mathrm{~g} / \mathrm{mL}$ according to the convenience of the raw material (cajuput) used is too much (solid) and almost filled the sample flask. It cause the vapor difficult to penetrate inside the material diffuses out the essential oil of the material. The amount of the material is closely related to the large space between materials. The excessively high and uneven amount of materials cause the formation of vapor lines that can be decreased the yield and quality of essential oils [21].

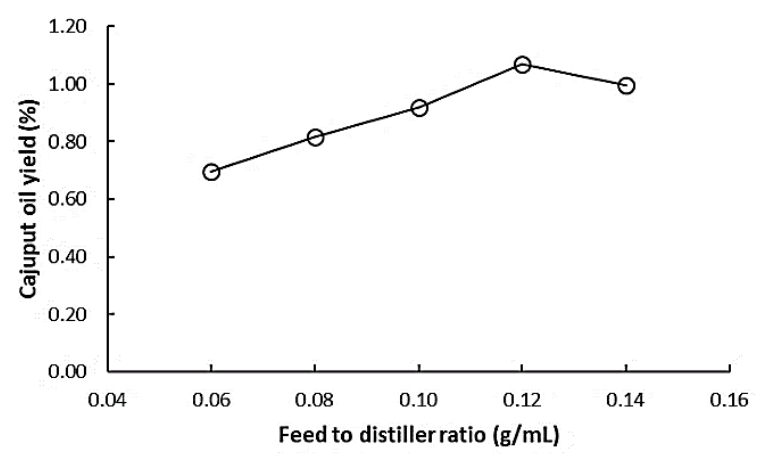

Fig. 1. Yield profile of cajuput oil as function of the feed to distiller $(\mathrm{F} / \mathrm{D})$ ratio

Figure 2 shows an increase in product yield when the microwave power is increased. It is known that the microwave power of extraction process will controlled the amount of energy received by plant material, hence to be converted into heat energy. This heat energy helps the process of removal of essential oils from plant material or sample. The power effect on the yield for the solvent-free microwave extraction method can be interpreted as the greater the microwave power used, the greater the energy received by the plant material to be converted into heat which eventually results in lower 
yields of cajuput oil. This case occurs because of thermal degradation of the material.

In this study, the optimum yield oil extracted by solvent-free microwave extraction was higher when compared with conventional method like hydrodistillation or water-steam distillation. Based on previous research conducted by Pujiarti et al., 2011 [2], during 5 hours of extraction process using water-steam distillation method obtained yield of $0.61 \pm 0.11 \%$.

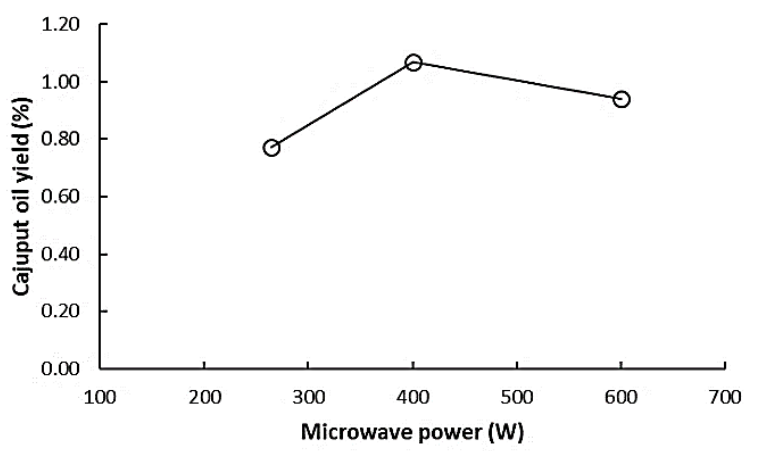

Fig. 2. Yield profile of cajuput oil as function of the microwave power

\subsection{Kinetic modelling of cajuput oil extraction with solvent-free microwave extraction method}

Figure 3 shows the first-order kinetic model results analyzed using a plot between $\log (\mathrm{Cs}-\mathrm{Ct})$ versus time, $\mathrm{t}$. In conventional methods of hydrodistilation, heat transfer and mass work in different times. The heat transfer occur from the gland to inside the cell when the temperature increased. Whereas the process of mass transfer occur from inside to outside to the gland when inside the cell was open.

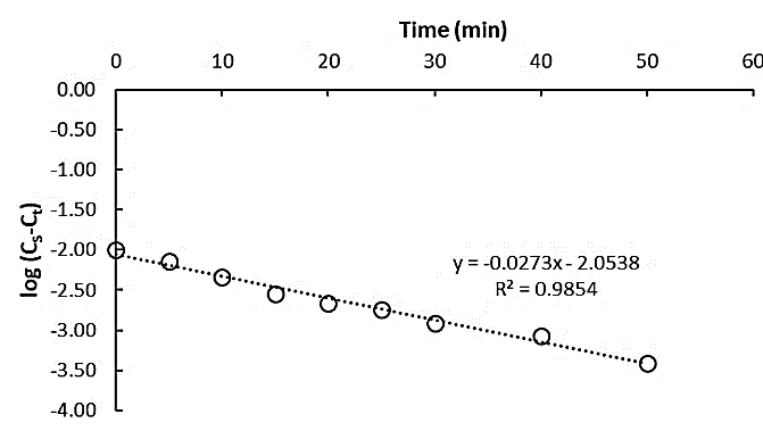

Fig. 3. First-order kinetics model of cajuput oil

Figure 4 shows the second-order kinetic model results analyzed using a plot between $\mathrm{t} / \mathrm{Ct}$ versus time, t. Based on Figure. 3 and 4, it can be seen that the reaction kinetics corresponding to the SFME method is a second-order kinetics model. This is related with the transfer of heat and mass moving in the same time and direction from the inside to the outside of the gland.

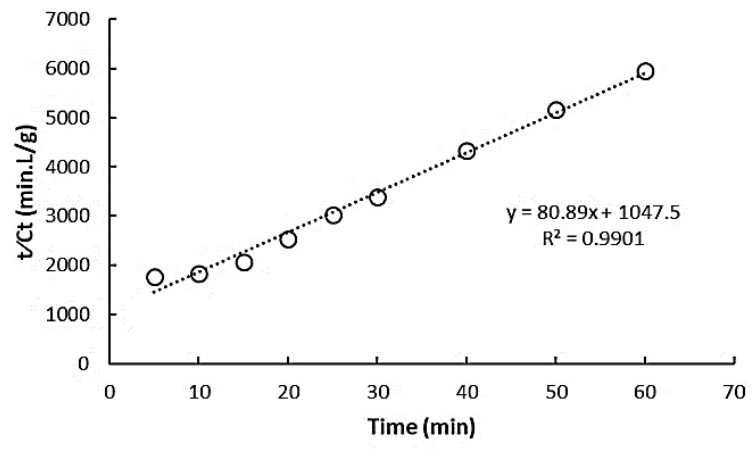

Fig. 4. Second-order kinetics model of cajuput oil

There is the comparison between first-order and second-order kinetics model that shown in table 1. Based on the data showed in Table 1, the coefficient of determination, $R^{2}$, second-order kinetics model can be better represent than first-order kinetics model.

Table 1. Comparison between first-order and secondorder kinetic model of solvent-free microwave extraction of Melaleuca leucadendra L.

\begin{tabular}{|l|l|l|l|}
\hline \multicolumn{4}{|c|}{ Kinetic model } \\
\hline \multicolumn{2}{|c|}{ First-order } & \multicolumn{2}{c|}{ Second-order } \\
\hline $\mathrm{k}_{1}\left(\mathrm{~L} \mathrm{~g}^{-1} \mathrm{~min}^{-1}\right)$ & 0.0629 & $\mathrm{k}_{2}\left(\mathrm{~L} \mathrm{~g}^{-1} \mathrm{~min}^{-1}\right)$ & 9.3877 \\
\hline $\mathrm{Cs}\left(\mathrm{gL}^{-1}\right)$ & 0.0101 & $\mathrm{Cs}\left(\mathrm{gL}^{-1}\right)$ & 0.0124 \\
\hline \multirow{2}{*}{$\mathrm{R}^{2}$} & \multirow{2}{*}{0.9854} & $\mathrm{~h}\left(\mathrm{~g} \mathrm{~L}^{-1} \mathrm{~min}^{-1}\right)$ & 0.0009 \\
\cline { 3 - 4 } & & $\mathrm{R}^{2}$ & 0.9901 \\
\hline
\end{tabular}

\section{Conclusion}

In this study, SFME resulted in a reduced extraction time and a substantial energy saving compared to the conventional method HD technique. The optimum yield in the extraction of cajuput oil using solvent-free microwave extraction method is $1.0674 \%$. Based on kinetics modeling that has been done, it can be said that the second-order kinetic model $\left(\mathrm{R}^{2}=0.9901\right)$ can be better represent experimental results of extraction of cajuput oil that using solvent-free microwave extraction method when compared with the first-order kinetic model $\left(\mathrm{R}^{2}=0.9854\right)$.

\section{References}

1. A. Widiyanto, M. Siarudin, Jurnal Penelitian Hasil Hutan 31 (4), 235-241 (2013).

2. R. Pujiarti, Y. Ohtani, H. Ichiura, J. Wood Sci. 57, 446-451 (2011).

3. E.S. Angela, W.L. Davis, Altern. Med. Rev. 15 (1), 33-47 (2010).

4. U.R. Juergens, U. Dethlefsen, G. Steinkamp, A. Gillissen, R. Repges, H. Vetter, Respir. Med. 97, 250-256 (2003).

5. J.J. Brophy, E.V. Lassak, Flavour Fragrance J. 3, 43-46 (1988).

6. M. Yatagai, T. Ohira, K. Nakashima, Biochem. Syst. Ecol. 26, 713-722 (1998).

7. A. Rimbawanto, M. Susanto, Prosiding Ekspose Hasil Litbang Bioteknologi dan Pemuliaan Tanaman Hutan, 83-92 (2004). 
8. Muyassaroh, Jurnal Teknik Kimia 10 (2), 36-39 (2016).

9. J.A. Pino, E.L. Regalado, J.L. Rodriguez, M.D. Fernandez, Chem. Biodiversity 7, 2281-2288 (2010).

10. B. Bayramoglu, S. Sahin, G. Sumnu, J. Food Eng. 88, 535-540 (2008).

11. M. Zill-e-Huma, J.F. Abert-Vian, F.C. Maingonnat, J. Chromatogr. A 1216, 7700-7707 (2009).

12. A. Farhat, C. Ginies, M. Romdhane, F. Chemat, J. Chromatogr. A 1216, 5077-5085 (2009).

13. S. Lagergen, K. Sven. Vetenskapsakad. Handl. 24(4), 1-39 (1989).

14. Z. Reddad, C. Gerente, Y. Andres, P.L. Cloirec, Environ. Sci. Technol. 36, 2067-2073 (2002).

15. Y-S. Ho, Scientometrics 59(1), 171-177 (2004).

16. H.S. Kusuma, M. Mahfud, RSC Adv. 7, 1336-1347 (2017).

17. H.S. Kusuma, T.I. Rohadi, E.F. Daniswara, A. Altway, M. Mahfud, Korean Chem. Eng. Res. 55(4), 574-577 (2017).

18. H.S. Kusuma, M. Mahfud, Int. Food Res. J. 24(4), 1697-1702 (2017).

19. H.S. Kusuma, M. Mahfud, ASEAN J. Chem. Eng. 15(2), 62-69 (2015).

20. H.S. Kusuma, P.D. Amelia, C. Admiralia, M. Mahfud, Commun. Sci. Technol. 1, 15-18 (2016).

21. E. Guenther, The Essential Oils Volume One: History, Origin in Plants, Production, Analysis, (1987). 